\title{
Analysis of Heavy Metals and Some Physicochemical Parameters in Soil of Major Industrial Dumpsites in Akure Township, Ondo State of South Western Nigeria
}

\author{
Iyabo Olabimpe Ojo ${ }^{1}$, James O. Ojo ${ }^{1} \&$ Osibanjo Oladele ${ }^{2}$ \\ ${ }^{1}$ Department of Chemistry, College of Education, Ikere-Ekiti, Ekiti State, Nigeria \\ ${ }^{1}$ Department of Chemistry, Federal University of Technology, Akure, Ondo State, Nigeria \\ ${ }^{2}$ Department of Chemistry, University of Ibadan, Oyo State, Nigeria \\ Correspondence: Iyabo Olabimpe Ojo, Department of Chemistry, College of Education, Ikere-Ekiti, Ekiti State, \\ Nigeria. Tel: 234-806-679-3330/234-805-110-1936. E-mail: bimfaitho@yahoo.com
}

Received: October 8, 2014 Accepted: October 24, 2014 Online Published: January 14, 2015

doi:10.5539/ijc.v7n1p55

URL: http://dx.doi.org/10.5539/ijc.v7n1p55

\begin{abstract}
Heavy metals and soil physicochemical parameters were identified as environmental pollutants in some major industrial dumpsites in Akure city of Ondo-State. The $\mathrm{pH}$ of the industrial dumpsites ranged from 4.87 to 6.74 with a mean value of 6.34 . The organic carbon for the industrial dumpsites ranged from $0.07 \%$ to $0.97 \%$, while the organic matter was between $0.13 \%$ and $1.68 \%$. The concentration of $\mathrm{Zn}, \mathrm{Fe}, \mathrm{Cu}, \mathrm{Pb}, \mathrm{Cd}, \mathrm{Ni}$ and $\mathrm{Cr}$ in $\mu \mathrm{g} / \mathrm{g}$ in all the industrial dumpsites A, B, C ranged between 237.60 - 486.00, 174.40 - 499.20, $18.00-114.00,20.60-$ $249.20,1.06-2.65,30.26-70.58$, and $30.50-68.08$ respectively. Also the contamination/pollution index of $\mathrm{Zn}$, $\mathrm{Fe}, \mathrm{Cu}, \mathrm{Pb}, \mathrm{Cd}, \mathrm{Ni}$, and $\mathrm{Cr}$ all the industrial dumpsites. A, B, C ranged between 1.69-3.47, not detected, 0.50-3.17, 0.24-2.53, 1.33-3.23, 0.86-2.01, and 0.31-0.68 respectively Pearson Correlation indicated that $\mathrm{Fe}, \mathrm{Zn}$, $\mathrm{Ni}$ and $\mathrm{Pb}$ were highly significant $(\mathrm{p}<0.01)$.
\end{abstract}

Keywords: heavy metals, physicochemical parameters, pollutants, dumpsites

\section{Introduction}

Akure city lies between latitude $7^{\circ} 17^{\prime} \mathrm{N}$ and longitude $5^{\circ} 16^{\prime} \mathrm{E}$ in the southwestern part of Nigeria. The ancient urban city has experienced increase in population and industrial activities in the last few decades since it has became the capital of Ondo state. In order to meet up with man's daily needs, a lot of industries were established in the state capital from which quantities of solid wastes are generated from industrial activities. These extensive industrial activities in the city have led to the re-developing of dumpsites covering an expanse of land for industrial purposes (Adefemi, Awokunmi, 2009). Therefore the level of heavy metals and some physicochemical parameter in the dumpsite soil are assayed. Soil is known to be the product of climate and living organism on rocks, and its nature is determined by the composition of parent rocks, type of climate and its age. It is essential to human because it is the top layer of the earth in which all the living things both plant and animals directly and indirectly take their food (Adefemi, Awokunmi, 2009).

Heavy metal is a member of a loosely defined subsets of element that exhibit metallic properties with relative high atomic weight, density and with a specific gravity of 5.0 or greater (Ademoroti, 1996). Heavy metals have been known to disrupt ecosystem structure and functioning for a long time. They are present as part of biogeochemical framework and as an essential trace elements for way life forms but above certain concentration are toxic to species. The negative effect of heavy metals depend on the concentration as well as on series of physical and chemical soil specific characteristics such as texture, organic matter content, $\mathrm{pH}$, redox potential and hydraulic conductivity etc.

The indiscriminate dumping of waste has become a common practice, and the composition of industrial waste dumps varies widely with many industrial \& human activities located near the dumpsites. Hence the health risk due to heavy metals contamination cannot be overemphasized, and is widely reported (Baker et al. 2000, Duruibe et al., 2007). Therefore the aim of this study was to determine the levels of heavy metals and some 
physicochemical parameters in soil of major industrial dumpsites in Akure township, the capital of Ondo-State of South Western Nigeria.

\section{Materials and Methods}

\subsection{Sampling and Sample Collection}

Soil samples within the depth of $0-15 \mathrm{~cm}, 15-30 \mathrm{~cm}$, and $30-45 \mathrm{~cm}$ were taken with the aid of an auger from the 3 different major dumpsites (Table 1) by Alter (Alter, N. 1989) method. The collected soil sample was carefully transferred into a black polythene bags, properly labelled and transported to the laboratory.

\subsection{Sample Preservation}

Samples were air-dried for about two weeks and sieved to $2 \mathrm{~mm}$ by mesh to prevent chemical microbial changes and to remove large mineral inclusions and organic debris. The sieved samples were stored in labelled polythene bags and used for subsequent analysis.

\subsection{Metal Determination}

The air-dried sample was pulverized by pounding it in a mortar. About $1 \mathrm{~g}$ was weighed for each sample into $250 \mathrm{ml}$ conical flask, $25 \mathrm{ml}$ of the acid mixture was poured on $1 \mathrm{~g}$ of the sample and was heated on the hot plate for about 30 minutes. After heating, it was allowed to cool for about 25 minutes. The solid was filtered using Whatman filter paper. The volume of the digest was diluted to $100 \mathrm{ml}$ with distilled water in a standard flask and was analyzed for heavy metals using the atomic absorption spectrophotometer (AAS).

\subsection{Organic Carbon}

The Walkey-Black (A. Walkey and I A. Black 1984) method was used in the determination of organic in the soil. $2 \mathrm{~g}$ of sieved soil was weighed out accurately into conical flask depending on the organic carbon content of the soil which could be estimated from the colour and finesse of such soil samples. $10 \mathrm{ml}$ of $1 \mathrm{~N} \mathrm{~K}_{2} \mathrm{Cr}_{2} \mathrm{O}_{7}$ standard solution was added to the soil followed by $20 \mathrm{ml}$ of concentrated $\mathrm{H}_{2} \mathrm{SO}_{4}$ to prevent the interference of chloride ions. The system was allowed to stand for 30 minutes with occasional swirling. After 30 minutes the content of the conical flask was diluted with $10 \mathrm{ml}$ of distilled water.

The excess $\mathrm{K}_{2} \mathrm{Cr}_{2} \mathrm{O}_{7}$ was determined by titrating with standard $1.0 \mathrm{~N}$ ferrous sulphate solution using ferroin as indicator. The blank titration was carried out in the same manner without the soil.

\subsection{Calculations}

The percentage organic carbon (air-dried basis) was calculated as follows:

$$
\% \text { organic carbon }=\left(\mathrm{M}_{\underline{2}} \underline{\mathrm{K}_{2}} \underline{\mathrm{Cr}_{2}} \underline{\mathrm{O}_{7}}-\mathrm{M}_{\underline{e}} \underline{\mathrm{FeSO}_{4}}\right) \times 0.003 \times 100 \times \mathrm{F}
$$

\section{Weight of Soil (g)}

$\mathrm{M}_{\mathrm{e}}=$ Normality of solution $\times$ Volume $(\mathrm{ml})$ of solution used

$\mathrm{F}=$ correlation factor $=1.33$

$\%$ organic matter in soil $=$ organic carbon $\times 1.729$

\subsection{Soil pH}

The $\mathrm{pH}$ of the soil sample was determined with a pH meter, model: Kent EK 7020 according to the method of Mclean [E.O. Mclean 1996].

\section{Results and Discussion}

Table 1 shows the sample site, the location of the dumpsite, type and the period that the site had been in existence.

Table 1. Industrial dumpsites locations within Akure metropolis.

\begin{tabular}{llll}
\hline Sample site & Location of dumpsite & Type & Year of existence \\
\hline Site A & $\begin{array}{l}\text { Mechanical workshop, opposite Michelin tyre } \\
\text { Depot, Ilesha-Road, Akure. }\end{array}$ & Industrial dumpsite & 18 years \\
Site B & $\begin{array}{l}\text { Welding and metal workshop, near Fanibi junction, } \\
\text { Ondo Road, Akure. }\end{array}$ & Industrial dumpsite & 15 years \\
Site C & $\begin{array}{l}\text { Mechanical / welding workshop near TISCO } \\
\text { disinfectants manufacturing company } \\
\end{array}$ & Industrial dumpsite & 15 years \\
& Supermarket, Ado-Ekiti Road, Akure & & \\
\hline
\end{tabular}


The variation of percentage organic matter with depth in site A was revealed in Table 2 . The percentage organic matter which depends on organic carbon is highest at depth $0-15 \mathrm{~cm}$ with a value of $1.68 \%$ and least at depth $30-45 \mathrm{~cm}$ with $0.80 \%$ value. This is attributed to the fact that the top soil usually contains more plant residue and vegetation leading to greater plant productivity than lower layers of the soil. These values compare well with similar work done in Industrial Estate of Lagos-State (Ikuyajesin, A. K. 2002).

Table 2 also shows the variation of $\mathrm{pH}$ with depth of soil. The $\mathrm{pH}$ is least and with a value of 6.54 at $0-15 \mathrm{~cm}$ depth and highest with the value of 6.70 at $15-30 \mathrm{~cm}$ depth which is consistent with similar work done at some industrial sites in Akure (Oguntimehin, I. 2002).

Table 2. Percentage organic matter / organic carbon and $\mathrm{pH}$ value in site A.

\begin{tabular}{llll}
\hline Depth (cm) & Organic Matter Percentage & Organic Carbon Percentage & pH \\
\hline $0-15$ & $1.68 \%$ & $0.97 \%$ & 6.54 \\
$15-30$ & $1.20 \%$ & $0.69 \%$ & 6.70 \\
$30-45$ & $0.60 \%$ & $0.35 \%$ & 6.65 \\
\hline
\end{tabular}

Fig. 1 shows the variation of metal concentrations with depth in site A. The concentration ranges from $2.20 \mu \mathrm{g} / \mathrm{g}$ at $30-45 \mathrm{~cm}$ depth to $499.20 \mu \mathrm{g} / \mathrm{g}$ in $\mathrm{Fe}$ at a depth of $0-15 \mathrm{~cm}$. it was observed that the concentration of some metals like $\mathrm{Fe}, \mathrm{Zn}, \mathrm{Ni}, \mathrm{Pb}$ and $\mathrm{Cr}$ were higher than that of $\mathrm{Cu}$ and $\mathrm{Cd}$. Iron $(\mathrm{Fe})$ was expectedly high in this area than other metals due to the proximity mechanical workshop. The high values of $\mathrm{Fe}, \mathrm{Zn}, \mathrm{Ni}, \mathrm{Pb}$ and $\mathrm{Cr}$ in the soil sample from these mechanical operation activities contributed significantly to the concentration levels of the metals. The very high value for Fe was also observed in a related study by Abata et al (2013) evaluated the level of heavy metals like $\mathrm{Cd}, \mathrm{Cr}, \mathrm{Fe}, \mathrm{Ni}, \mathrm{Pb}$ and $\mathrm{Zn}$ in the sediments of Ala Rivers that runs through Akure metropolis.

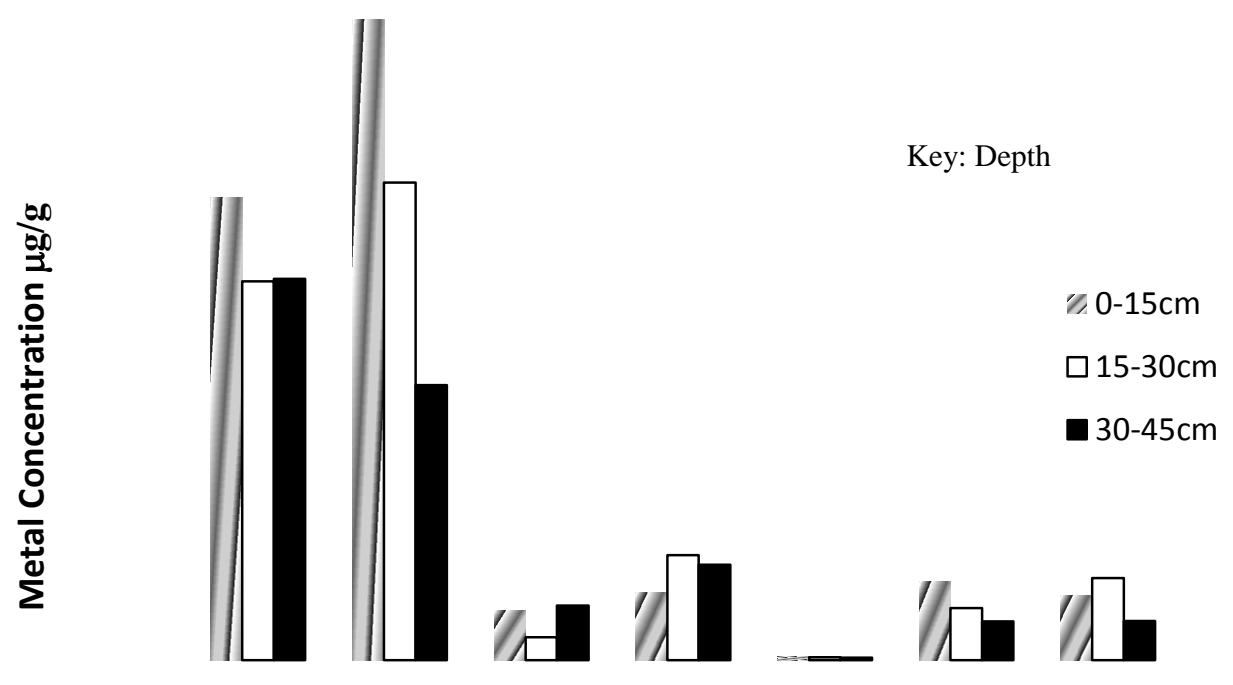

Metal Samples

Figures 1. Variation of Metal Concentration with Different In Soil in Site A

Table 3 shows the variation of organic matter with depth and $\mathrm{pH}$ value for industrial dumpsites $\mathrm{B}$. The values range from 0.24 to $0.58 \%$. It was observed that the percentage organic is highest with a value of 0.58 at $0-15 \mathrm{~cm}$ depth and least with a value of 0.24 at $30-45 \mathrm{~cm}$ depth. Table 3 also presents the variation of soil $\mathrm{pH}$ with depth for site B. The $\mathrm{pH}$ ranges between 6.20 and 6.73. It was observed to be least at the depth $15-30 \mathrm{~cm}$ with a value of 6.20 and highest at the depth $0-15 \mathrm{~cm}$ with a value of 6.73 . 
Table 3. Percentage organic matter/organic carbon values for soil in site B (Industrial dumpsite.)

\begin{tabular}{llll}
\hline Depth (cm) & Organic Matter Percentage & Organic Carbon Percentage & pH \\
\hline $0-15$ & $0.58 \%$ & $0.33 \%$ & 6.74 \\
$15-30$ & $1.42 \%$ & $0.24 \%$ & 6.20 \\
$30-45$ & $0.24 \%$ & $0.14 \%$ & 6.45 \\
\hline
\end{tabular}

The variation of metal concentration with different depths industrial dumpsites B were given in Figure 2 metal concentrations ranges between $1.6 \mu \mathrm{g} / \mathrm{g}$ in $\mathrm{Cd}$ at a depth $30-45 \mathrm{~cm}$ to $486 \mu \mathrm{g} / \mathrm{g}$ in $\mathrm{Zn}$ at a depth of $0-15 \mathrm{~cm}$. In this dumpsite, the level of heavy metals like $\mathrm{Zn}, \mathrm{Fe}, \mathrm{Cu}, \mathrm{Pb}, \mathrm{Cd}, \mathrm{Ni}$ and $\mathrm{Cr}$ were evaluated in the soil samples. The high values for $\mathrm{Zn}, \mathrm{Fe}, \mathrm{Ni}$ and $\mathrm{Cu}$ may be due to the nearness of the dumpsite for $\mathrm{Zn}$ and $\mathrm{Fe}$ were also observed in a similar study by Ogunmodede et al, (2013) who investigated the heavy metal and microbial loads of some dumpsites soil in Ado-Ekiti and Ijero-Ekiti.
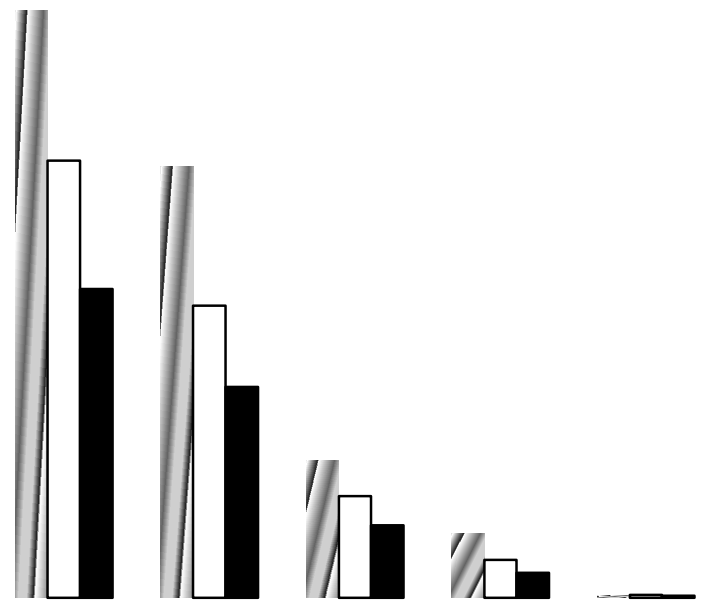

Key: Depth

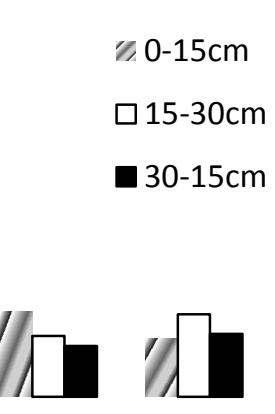

\section{Metal Samples}

Figure 2. Variation of Metal Concentration with Different Depth in Soil Site B

Table 4 reveals the percentage organic matters/organic carbon and $\mathrm{pH}$ values for organic soil in site $\mathrm{C}$. The percentage organic matter ranges from $0.13 \%$ to $0.58 \%$. It is highest at depth $0-15 \mathrm{~cm}$ depth with a value of $0.58 \%$ and least at depth $30-45 \mathrm{~cm}$ with $0.13 \%$ value which may be attributed to the fact that top soil usually contains more plant residue and vegetation. Table 4 also shows the variation of $\mathrm{pH}$ with the depth of soil. The $\mathrm{pH}$ is least and with a value of 6.64 and $0-15 \mathrm{~cm}$ depth which is similar to work done in a particular industrial dumpsite in Akure.

Table 4. Percentage organic matter / carbon and $\mathrm{pH}$ values for soil site $\mathrm{C}$.

\begin{tabular}{llll}
\hline Depth (cm) & Organic Matter Percentage & Organic Carbon Percentage & pH \\
\hline $0-15$ & $0.58 \%$ & $0.33 \%$ & 6.64 \\
$15-30$ & $0.32 \%$ & $0.18 \%$ & 6.23 \\
$30-45$ & $0.13 \%$ & $0.07 \%$ & 4.87 \\
\hline
\end{tabular}

Figure 3 shows the variation of metal concentration with depth in industrial dumpsites $\mathrm{C}$. The concentration of the metals ranges from $1.06 \mu \mathrm{g} / \mathrm{g}$ in $\mathrm{Cd}$ at a depth $15-30 \mathrm{~cm}$ to $424.80 \mu \mathrm{g} / \mathrm{g}$ in $\mathrm{Zn}$ at a depth $0-15 \mathrm{~cm}$. High values of $\mathrm{Zn}, \mathrm{Fe}, \mathrm{Pb}$ and $\mathrm{Cu}$ may be due to the proximity of mechanic, battery charger and welding metal workshops around the dumpsites area.

Pearson correlation indicated that $\mathrm{Fe}, \mathrm{Zn}, \mathrm{Ni}$ and $\mathrm{Cr}$ were highly significant $(\mathrm{p}<0.01)$, suggesting the anthropogenic courses of these metals in the dumpsites soil under study. 


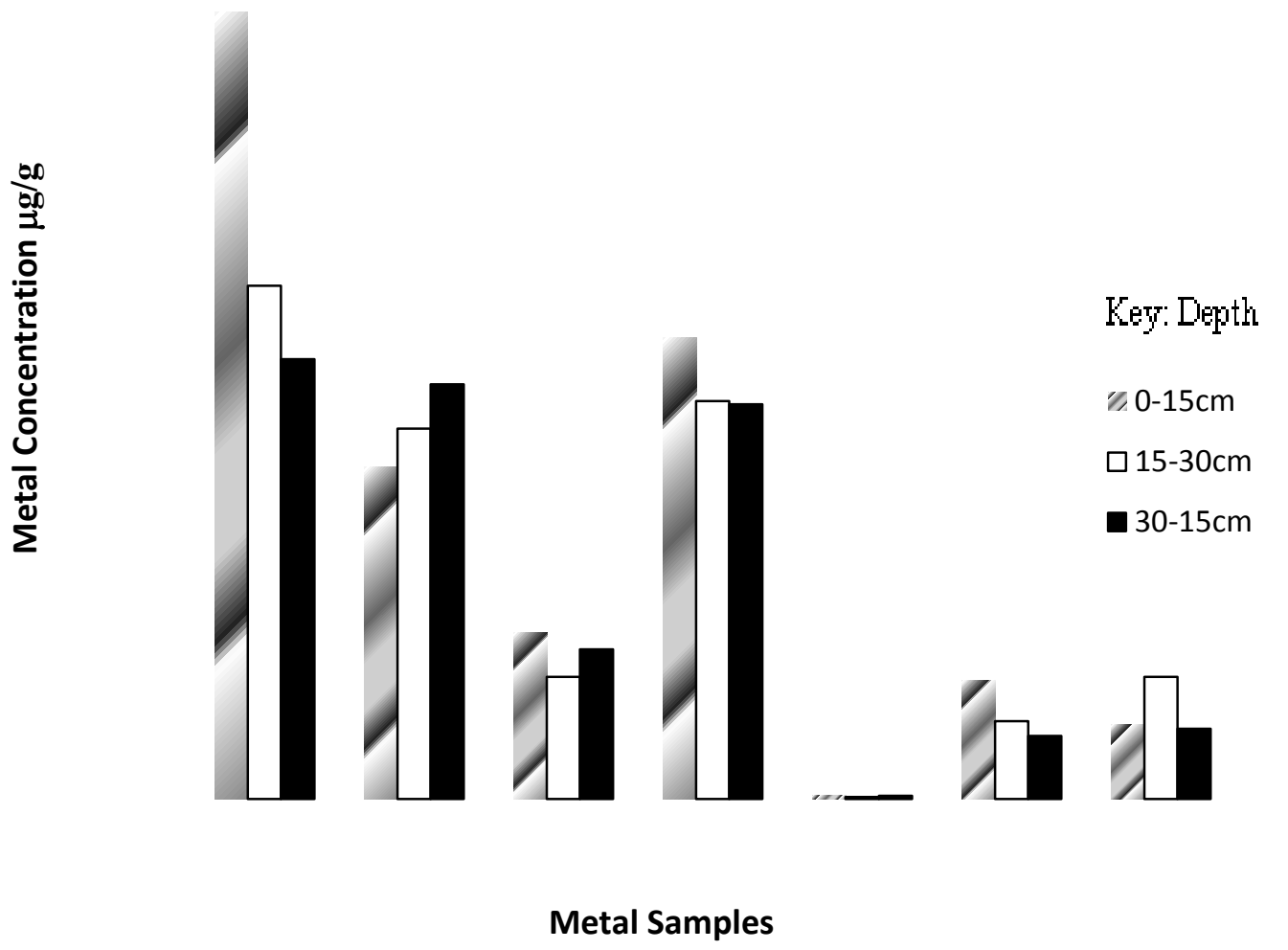

Figure 3. Variation of Metal Concentration with Different Depth in Soil Site C

Table 5 reveals the maximum allowable limit (M.A.I) for heavy metals concentration ( $\mathrm{mg} / \mathrm{kg}$ ) use in Nigeria as set by the department of petroleum resources (DPR) in 1991.

Table 5. Values of maximum allowable limits (M.A.L) for heavy metals in soil ( $\mathrm{mg} / \mathrm{kg}$ ) used in Nigeria.

\begin{tabular}{lll}
\hline Metals & Target value $(\mathbf{m g} / \mathbf{k g})$ & Intervention values $(\mathbf{m g} / \mathbf{k g})$ \\
\hline Barium & 200.00 & 5000.00 \\
Cadmium & 0.80 & 17.00 \\
Chromium & 100.00 & 380.00 \\
Copper & 36.00 & 190.00 \\
Mercury & 0.30 & 10.00 \\
Lead & 85.00 & 530.00 \\
Nickel & 35.00 & 210.00 \\
Zinc & 140.00 & 720.00 \\
Cobalt & 20.00 & 240.00 \\
\hline
\end{tabular}

Source: DPR Guidelines (1991)

Table 6 reveals the contamination / pollution index for site A, B, C while Table 7 shows the significance of intervals of contamination/pollution index as reported by Department of Petroleum Resources (DPR, 1991). At a depth of $0-15 \mathrm{~cm}$, the pollution index values $2.57,1.08,3.23$ and 1.74 for $\mathrm{Zn}, \mathrm{Cu}, \mathrm{Cd}$, and $\mathrm{Ni}$ respectively exist at the level of pollution while the pollution index values 0.62 and 0.50 for $\mathrm{Pb}$ and $\mathrm{Cr}$ respectively exist at the level of contamination. At a depth of $15-30 \mathrm{~cm}$, the pollution index values $2.10,2.28$, and $1.16 \mathrm{for} \mathrm{Zn}, \mathrm{Cd}$, and $\mathrm{Ni}$ respectively confirmed the presence of the elements at pollution levels while $0.50,0.96$, and $0.64 \mathrm{for} \mathrm{Cu}, \mathrm{Pb}$, and $\mathrm{Cr}$ confirmed the presence of element at contamination levels. At a depth of $30-45 \mathrm{~cm}$, the values $2.12,1.18$, and 2.76 for $\mathrm{Zn}, \mathrm{Cu}$, and $\mathrm{Cd}$ respectively confirmed their presence at pollution level while values $0.88,0.86$, and 0.31 for $\mathrm{Pb}, \mathrm{Ni}$, and $\mathrm{Cr}$ confirmed their presence at contamination level. 
The contamination/pollution index for industrial dumpsite $\mathrm{B}$. at site $\mathrm{B}$, at depth of $0-15 \mathrm{~cm}$, shows that $\mathrm{Zn}, \mathrm{Cu}$, $\mathrm{Cd}$, and $\mathrm{Ni}$ with values 3.47, 3.17, 2.85, and 2.01 respectively were present at the level of pollution while $\mathrm{Pb}$ and $\mathrm{Cr}$ with values 0.62 and 0.48 respectively were present at contamination level. At depth $15-30 \mathrm{~cm} \mathrm{Zn}, \mathrm{Cu}, \mathrm{Cd}$, and $\mathrm{Ni}$ with values $2.58,2.33,2.85$ and 1.43 are present at pollution level while $\mathrm{Pb}$ and $\mathrm{Cr}$ with values 0.37 and 0.68 are present at the level of contamination. At the depth $30-45 \mathrm{~cm}, \mathrm{Zn}, \mathrm{Cu}, \mathrm{Cd}$, and $\mathrm{Ni}$ with values $1.83,1.67$, 2.02 , and 1.20 respectively are pollutants while $\mathrm{Pb}$ and $\mathrm{Cr}$ with values 0.24 and 0.52 respectively are contaminants.

Also, table 6 reveals the contamination/pollution index for industrial dumpsite C. At site $\mathrm{C}$ at a depth of $-15 \mathrm{~cm}$, the pollution index values 3.03, 2.50, 2.53, 2.69, and 1.83 for $\mathrm{Zn}, \mathrm{Cu}, \mathrm{Pb}, \mathrm{Cd}$, and $\mathrm{Ni}$ respectively confirmed the presence of the elements at pollution levels while the value 0.41 for $\mathrm{Cr}$ confirmed its presence at contamination level. At a depth $15-30 \mathrm{~cm}$ the pollution index values $1.98,1.83,2.50,1.33$, and 1.20 for $\mathrm{Zn}, \mathrm{Cu}, \mathrm{Pb}, \mathrm{Cd}$, and $\mathrm{Ni}$ respectively are pollutants while $\mathrm{Cr}$ exists at contaminants. At a depth of $30-45 \mathrm{~cm}$ the pollution index values $1.69,2.25,2.50,2.28$ for $\mathrm{Zn}, \mathrm{Cu}, \mathrm{Pb}$, and $\mathrm{Cd}$ respectively confirmed the presence of the elements at pollution levels while the value 0.97 and 0.08 for $\mathrm{Ni}$ and $\mathrm{Cr}$ confirmed the presence at contamination level.

Table 6. Contamination / Pollution (C/P) values for metals in sites A, B, C

\begin{tabular}{|c|c|c|c|c|c|c|c|c|}
\hline & Depth $(\mathrm{cm})$ & $\mathrm{Zn}^{2+}$ & $\mathrm{Fe}^{2+}$ & $\mathrm{Cu}^{2+}$ & $\mathrm{Pb}^{2+}$ & $\mathrm{Cd}^{2+}$ & $\mathrm{Ni}^{2+}$ & $\mathrm{Cr}^{2+}$ \\
\hline \multirow{3}{*}{$\begin{array}{l}\ll \\
\stackrel{0}{\sigma}\end{array}$} & $0-15$ & 2.57 & 0.00 & 1.08 & 0.62 & 3.23 & 1.74 & 0.50 \\
\hline & $15-30$ & 2.10 & 0.00 & 0.50 & 0.96 & 2.28 & 1.16 & 0.64 \\
\hline & $30-45$ & 2.12 & 0.00 & 1.18 & 0.88 & 2.76 & 0.86 & 0.31 \\
\hline \multirow{3}{*}{$\stackrel{\oplus}{\stackrel{\oplus}{\sigma}}$} & $0-15$ & 3.47 & 0.00 & 3.17 & 0.62 & 2.85 & 2.01 & 0.48 \\
\hline & $15-30$ & 2.58 & 0.00 & 2.33 & 0.37 & 2.85 & 1.43 & 0.68 \\
\hline & $30-45$ & 1.83 & 0.00 & 1.67 & 0.24 & 2.02 & 1.20 & 0.52 \\
\hline \multirow{3}{*}{$\begin{array}{l}\text { U } \\
\stackrel{0}{:}\end{array}$} & $0-15$ & 3.03 & 0.00 & 2.50 & 2.53 & 2.69 & 1.83 & 0.41 \\
\hline & $15-30$ & 1.98 & 0.00 & 1.83 & 2.50 & 1.33 & 1.20 & 0.66 \\
\hline & $30-45$ & 1.69 & 0.00 & 2.25 & 2.50 & 2.28 & 0.97 & 0.38 \\
\hline
\end{tabular}

Table 7. Significance of intervals of contamination/pollution index

\begin{tabular}{lll}
\hline $\mathbf{C} / \mathbf{P}$ & Significance & Symbol \\
\hline$<0.1$ & Very Slight Contamination & v.s.c. \\
$0.10-0.25$ & Slight Contamination & s.c. \\
$0.26-0.50$ & Moderate Contamination & m.c. \\
$0.51-0.75$ & Severe Contamination & s.c. \\
$0.76-1.00$ & Very Severe Contamination & v.s.c. \\
$1.10-2.00$ & Slight Pollution & s.p. \\
$2.10-4.00$ & Moderate Pollution & m.p. \\
$4.10-8.00$ & Severe Pollution & s.p. \\
$8.10-16.00$ & Very Severe Pollution & v.s.p. \\
$>16.00$ & Excessive Pollution & e.p. \\
\hline
\end{tabular}

Source: DPR guidelines (1991).

\section{Conclusion}

All the soil sites are heavily polluted with metals and the highest multiple pollution values was found with site $\mathrm{C}$ which has the value of 32.56 while the industrial site B is the least polluted with a multiple pollution value of 25.49. The fact that the highest observed value is from site $\mathrm{C}$ is exciting and might be due to everyday industrial activity that goes on around the site. The mechanics and the workers in the disinfectant manufacturing industry normally dispose their industrial waste every day.

All the metals except chromium have concentrations above the Nigerian target value as published by the Department of Petroleum Resources (DPR) in Nigeria (1991) but with none of the values reaching the intervention value.

\section{Recommendation}

Since all the soils have metal concentrations above the target values, (except chromium). It is therefore recommended that soil remediation techniques (Chaudri, A.M. 2001) should be carried out on all the dumpsites sampled in this research work. 
Government should discourage the indiscriminating sitting of mechanics, welding workshops, and manufacturing company in places where wastes could not be centrally collected and reprocessed in an environmentally sound manner.

\section{References}

Abata, E. O., Aiyesanmi, A. F., Adebayo, A. O., \& Ajayi, O. O. (2013). Assessment of Heavy Metal Contamination and Sediment Quality in the Urban River: A case study of Ala River in Southwestern-Nigeria. Journal of Applied Chemistry, 4(3), 56-63.

Adefemi, O. S., \& Awokunmi, E. E. (2009). The Impact of Municipal Solid Waste Disposal in Ado Ekiti Metropolis, Ekiti State, Nigeria. Afri. J. of Environ. Sci and Tech., 3(8), 186-191.

Ademoroti, C. M. A. (1996). Standard Methods of Chemical Analysis (pp. 45). March Print and Consultancy Benin, Nigeria.

Aller, N. (1989). Handbook of Suggested Practices for Design and Installation of Groundwater, Monitoring Wells, EPA/600/4-89/034. Published by NWWA, Dubling.

Babur, C. (1992). A Survey of Metal Levels in Street Dusts in Inner London Neighbourhood. Enviro. Inter., 18, 263-270. http://dx.doi.org/10.1016/0160-4120(92)90109-H

Baker, B. Y. (1992). Procedure Recommended for Overburdens and Hydrological Studies of Surface Mines. John Wiley pub. Paris France.

Batjes, N. H. (1996). Total Carbon and Nitrogen in the Soils of the world. European J. Soil Sci., 47, 151-163. http://dx.doi.org/10.1111/j.1365-2389.1996.tb01386.x

Blaylock, M. J., Salt, D. E, Dushenkov, S., Zakharova, O., \& Gussman, C. (1998). Field Demonstration of Phytoremediation of Lead Contaminated Soils, In Phytoremediation proceedings of the 4th international Conference on the Biogeochemistry of Trace Elements.

Boulding, J. R. (1994). Description and Sampling of Contaminated Soils. Lewis Publisher N.Y. Second edition A10.

Chaudri, A. M. (2001). Organic Pollutants: Fate in Soil and Remediation IACR -Rothamsted. Conference paper delivered at the FAD.IB Conference, Enugu (Personal Communication).

Chlopecka, A., Bacon, J. R., Wilson, M. J., \& Kay, J. (1996). Forms of Cadmium, Lead and Zinc in Contaminated Soils from South West Poland. Jour of Environ Qual, 25, 69-79. http://dx.doi.org/10.2134/jeq1996.00472425002500010009x

DPR. (1991). DPR Environmental Guidelines and Standard for the Petroleum Industry in Nigeria.

Gregory, D. J., Ronald, E. S., \& Mary, B. C. (1996). Metals in Drinking Water, North Carolina Cooperative Extension Service Publication No AG - 473-1.

Halavay, J., Antal, P., \& Karpatiy, K. (1993). Distribution of Toxic Metals in Soil Dusts Collected at Different Workshops. Sci of the Total Environ, 136, 93-99. http://dx.doi.org/10.1016/0048-9697(93)90299-L

Holmgren, G. S. S., Meyer, M. W, Chancy, P. L, \& Daniels, R. B. (1993). Cadmium, Lead, Zinc, Copper and Nickel in Agricultural Soil of the United States of America J. Environ. Qual., 22, 335- 348. http://dx.doi.org/10.2134/jeq1993.00472425002200020015x

Hung, J. W., Blaylock., M. J, Kapulnik, Y., \& Ensley, B. D. (1995). Phytoremediation of Uranium Contaminated soils: Role of Organic Acids in Trigging Uranium Hyperaccumulation in plants. Environ. Set. Tech., 32, 2004-2008. http://dx.doi.org/10.1021/es971027u

Hung, J. W., Chen. J. J, Berti W. R., \& Cunningham, S. D. (1997). Phytoremediation of Lead Contaminated Soils: Role of Synthetic Chelates in Lead Phytoextraction. Environ. Sci. Tech., 31, 800 - 805. http://dx.doi.org/10.1021/es9604828

Ogunmodede, O. T., Ajayi, O. O., Amoo, 1. A., \& Adewole, E. (2013). Characterization of Dumpsite Soil: Case Study of Ado-Ekiti and Ijero-Ekiti, Nigeria. Journal of Environmental Science, Toxicology and Food Technology, 3(6), 43-50.

\section{Copyrights}

Copyright for this article is retained by the author(s), with first publication rights granted to the journal.

This is an open-access article distributed under the terms and conditions of the Creative Commons Attribution license (http://creativecommons.org/licenses/by/3.0/). 